\title{
Drunk driving in the Czech Republic: Motivation, risk-reducing strategies, and opinions about sanctions
}

\author{
Petr Zámečník ${ }^{b}$ Václav Linkov ${ }^{a *}$, Nikol Nesvadbováa \\ ${ }^{a}$ Transport Research Centre (CDV), Líšeňská 33a, Brno 63600, Czech Republic \\ ${ }^{b}$ Department of psychology, PalackýUniversity, \\ *Corresponding author: vaclav.linkov@cdv.cz
}

\begin{abstract}
We examined Czech drunk drivers and their opinions and beliefs about drunk driving, strategies to avoid being caught, and their understanding of the associated legal punishments. Two focus groups were conducted with a total of 10 people who had suspended driving licenses and who had experience with driving under the influence of alcohol. The participants incorrectly believed that a small amount of alcohol does not influence their driving behavior. Some of them incorrectly believed that alcohol might be eliminated from the blood by eating, drinking water, using capsules, or having a short sleep. Most of them declared that they drove under the influence of alcohol because they thought that they were not drunk. Only some expressed that they drove under the influence willingly and repeatedly. Drunk driving was usually a weekend activity. They tried to avoid being caught by police by employing defensive strategies, like using side and one-way roads, driving in a traffic jam, traveling during early morning hours, concentrating excessively on their driving, and wearing inconspicuous clothes. They do not have precise knowledge about the legal sanctions for drunk driving. They are most afraid of having their driver's license suspended. They think that the sanctions are not fair, because they are not applied to all people in the same way.
\end{abstract}

KEYWORDS: Drunk driving; offenders' beliefs; motivation; attitudes about punishment.

\section{INTRODUCTION}

Many studies have shown that alcohol usage significantly impairs a driver's ability to concentrate on driving, stay in a traffic lane, and maintain a consistent speed. The risk of an accident increases exponentially with a concentration of alcohol in the blood (Šucha \& Štastná, 2015). Therefore, studying the reasons that people drive under the influence of alcohol (DUI) and the level of their knowledge about the possible consequences is important for improving traffic safety. In this study, we formed focus groups with drivers who had a suspended driver's license and examined their beliefs and attitudes towards DUI avoidance and the legal sanctions for this activity.

Several facts are well known about DUI. It is much more prevalent for men than for women (Portman et al., 2013). It is often connected with other law-breaking activities. Criminological studies that have analyzed police data of people convicted of a DUI found that the risk increases for people who had been arrested before the age of 16 , who had been imprisoned, who had previously been clients of a probation service, and who are judged by police as angry, emotional, untrustworthy, unkind, or unhappy. Drunk drivers are usually younger people. Surprisingly, the risk of a DUI in the United States decreases when people have more criminal peers, when they had been expelled from school, or when they had had other problems as a teenager (DeMichele, Lowe \& Payne, 2014).

Opinions and attitudes about drunk driving influence drivers' willingness to engage in this activity (Beck, 1981; McCarthy \& Pedersen, 2009). Majority of drivers believe that it is unlikely to be caught by police when driving while being drunk (Pinsky, Labouvie, Pandina \& Laranjeira, 2001). This belief is more common in areas with high injury crash rate and larger number of driving-related offenses (Beck, Yan, Wang, Krens \& Burch, 2009). Drunk driving offenders believe that sobriety checkpoints are less common than the general population believes (Goodfellow \& Kilgore, 2014). Drunk driving behavior is negatively associated with friends approval of such behavior and belief in high risk of accident or police 
stop (Greenberg, Morral \& Jain, 2004, 2005). This shows that it is important to know which opinions and attitudes about drunk driving are held among general population and among drunk drivers. The present research aims to provide information about this opinions in Czech drunk drivers population.

Drunk people might be influenced to not drive if their peers intervene. Such interventions are more successful if direct, like orders, than when they are indirect, like suggestions or requests (Shore \& Compton, 2000). The best avoidance strategy is a self-motivated limitation of alcohol consumption (Liourta \& van Empelen, 2008). A strong motivation to not drink and drive is the fear of losing one's driver's license. The suspension of a driver's license after a DUI has serious social consequences, especially the possibility of losing employment, having fewer opportunities in job seeking, and being dependent on others for transportation. The majority of drunk drivers in Australia find license suspension to be a fair punishment for a DUI; however, they do not agree with permanent license revocation. Seventy four percent of Australian drunk drivers drive even while their license is suspended (Lenton, Fetherston \& Cercarelli, 2010). Finbo (2014) describes three categories of drunk drivers regarding their relationship to the consequences of a DUI. The first category considers the punishment to be an integral part of a DUI. The second category considers a DUI and its consequences to be different stages of life and the punishment to be an unreasonable societal demand. And the third category of drivers consider a DUI and the potential resultant accident or punishment to be totally unrelated: driving drunk is just a momentary loss of control, and it could be repeated again.

Kulick and Rosenberg (2000) report that the most frequent categories of reasons used by drunk drivers in a sample of American students justified their behavior with the need to go home, the fact that the driver was the least drunk among the friends in the car, believing to have no other option, self-confidence in driving ability, geographical convenience, and the self-perception of not being so drunk. The most common strategies to drive while drunk were driving slowly, paying close attention to the driving and traffic rules, and taking side streets. Alonso, Pastoro, Montoro, and Esteban (2015) report the following reasons given by Spanish drunk drivers to justify this activity: not being able to otherwise get home; not feeling so influenced by alcohol; not realizing how much they had drunk; driving drunk is a normal thing that everyone does; and the adventurous desire to just enjoy life. Almost all Spanish drivers know that drunk driving is punishable by law; $96 \%$ know that they might lose their driver's license; $90 \%$ think that they might receive fine; and 70\% think that they might be arrested.

Alcohol in the blood is eliminated by the enzyme alcohol dehydrogenase (Zakhari, 2006). It is not possible to accelerate the elimination of alcohol from the blood by using any kind of substances. Nevertheless, it is possible to influence how much of the alcohol moves from the stomach and small intestine into the blood. Alcohol absorption in the stomach is sped up by drinking carbonated drinks (Ridout, Gould, Nunes, \& Hindmarch, 2003) and it is slowed by the amount of food in the stomach; this effect is larger for food rich in proteins and fat and lower for food rich in sugars (Watkins \& Alder, 1993). The absorption of alcohol is slower if drinks are colder. The amount of alcohol absorbed into the blood is also lowered by the use of medicines, like aspirin (Kechagias, Jonsson, Norlander, Carlsson, \& Jones, 1997). In our study we examined whether drivers had knowledge about the possibility of alcohol elimination.

Regarding the situation in the Czech Republic, the number of people who died or were seriously injured as a result of driving under influence of alcohol or drugs in 2015 was the largest number in the last five years. Currently there are about 1.5 million people in the risky alcohol user category, including 500,000 to 600,000 people who are addicted to alcohol or at a high risk of developing an alcohol addiction. Up to $40 \%$ of violent crimes and $9 \%$ of traffic accidents are caused by people under influence of alcohol (Mravčík 2014). Nowadays, 3.5\% drive under the influence of alcohol and 2\% drive under the influence of drugs (Schulze et al., 2012). The national strategy for traffic safety (Národní strategie bezpečnosti dopravního provozu) has declared its intention to reduce drunk driving to $0.01 \%$ of all drivers by 2020 .

Only a few drunk drivers are actually caught by police. A Swedish study reports that it takes about 200-2000 drives under the influence of alcohol to get caught (Hubicka, Laurell a Bergman, 2008). A similar American study showed that it took 50 drives to get caught (Hedlund a McCartt, 2002). Two-thirds of drunk drivers are stopped for violating a different traffic rule and only $10 \%$ are caught at ordinary traffic controls (Ojaniemi, Lintonen, Impinen, Lillsunde \& Ostamo, 2009). Suspects themselves think that other drivers regularly drive under influence (Mannstead, 
Parker, Stradling, Reason \& Baxter, 1992). For the Czech Republic, there is no data for how many drives it takes to get caught, but, because there are 5 million drivers and only half a million drivers controlled per year, the probability of being caught would be low.

Drunk driving is punishable by law in the Czech Republic and there is zero tolerance. If the amount of alcohol in the blood is below 1 per mill, it is considered an offense. Even this minor offense is punishable by a fine of up to 50,000 CZK (1910 EUR) and the suspension of the driver's license for six months to two years. If the amount of alcohol in the blood is above 1 per mill, it is a crime punishable by up to three years in prison, a fine up to $5,000,000 \mathrm{CZK}$ (190 000 EUR), suspension of the driver's license for one to 10 years, and/or community service for up to 300 hours (Švarc, 2014). The awareness of the level of criminalization for a DUI and about the possible punishment that every drunk driver may face is very important. Such awareness is not granted among the general population - e.g. drunk driving was criminalized in 2011 in China, but over $20 \%$ of convinced drunk drivers were unaware that it was a crime more than one year after the law's adoption (Jia et al., 2016). We, therefore, examined the awareness of the possible punishments for a DUI in this study.

\section{PARTICIPANTS AND METHOD}

As the aim of this research was the exploration of the above-mentioned phenomenon and our target population is very difficult to reach, the focus group method was selected for data gathering. We organized two focus groups. Participants were people whose driver's license had been suspended for traffic rules violations, usually a DUI. The first group had four participants, one woman and three men. The second group had six participants, all men. The participants were from 23 to 68 years old. Participants in focus groups had open discussion on topics given by moderator. Topics were based on the Czech traffic police needs for enhancement traffic safety measures. According to police reports from recent years, drunk driving and driving under influence of drugs are on the rise. Fighting these two issues is thus one of the main topics in the Czech national road safety strategy and traffic police is trying to find new knowledge and measures to fulfill its commitment to reduce the incidence of this phenomenon. Based on this goal several projects were started in 2015 and
2016 (e.g. TB0300MD01 - Assessing road safety using indirect indicators and following selected traffic safety actions 5 or LO1610 - The current situation in key traffic safety areas - alcohol, drugs, distractions). Main interest of traffic police are information about prevalence, subjective probability of caught, awareness about sanction and how is traffic police perceived by drivers so they could be able to plan countermeasures more precisely.

Focus group discussion was centered on the following themes: strategies to avoid a DUI; the frequency of drunk driving; and knowledge about the sanctions. Each focus group lasted approximately two hours. The focus groups were recorded and transcribed. The resulting transcripts were first analyzed for themes and conceptual categories (Powell \& Single, 1996; Rabiee, 2004). Subsequently, the transcripts were analyzed again with focus on the emerging themes using interpretative phenomenological analysis as inspiration (Smith, Flowers \& Larkin, 2009).

\section{RESULTS}

The specific answers of the participants illustrated our identified topics. The answers are divided according to defined areas.

\subsection{Motivation for drunk driving}

Participants mentioned that drivers might have started to drive when they felt sober, but they might not have yet been completely sober:

- P1: "Eighty percent drivers would not realize that they have residual alcohol... for me this was true. Always there was some (alcohol). .... When a man enters a car, he thinks he slept those $6,7,8$ hours..."

- P2: "You never know whether you are clear."

Other participants may have driven even if they knew that they were still a little bit drunk, because they thought the risk of getting caught was low:

- P2: "I knew I hadn't drunk for six hours and I knew I was not completely sober."

- P3: "Concerning the little bit of residual alcohol, before you are caught by police, you think that maybe you won't breathe anything (into the breathalyzer)."

- P10: "I'd drunk two stupid beers, which is OK for some and not for some." 
Participants might not have thought about what they were doing when they were drunk:

- P2: "I did not think that time. ... Something happened and I just drove, drove and didn't think about anything."

- P4: "I drove under the influence of alcohol, also under the influence of residual alcohol. My driving under influence was wittingly. ... In that good mood you want to do everything and it will come."

- P1: "People say, well, I had only two beers (one liter), so let's go."

People might have been afraid to leave their car alone, so they rather drove:

- P4: "You go downtown on Friday and you don't want to leave the car there, so you drive back."

A lack of money or the alleged unavailability of a service might have been responsible for not using drink-and-drive:

- P4: "You won't consider calling drink-anddrive when you've spent all your money for alcohol."

- P10: "There is no drink-and-drive service in the morning."

- P7: "They arrived after one hour. ... It is better to drive myself than to wait one hour."

The belief in the ability to avoid police control by choosing the appropriate road, clothing, or behavior, was also responsible for a DUI, because drivers trusted that they could avoid being caught:

- P4: "You should know the roads where policemen stand and where don't. They are not everywhere. On smaller roads and when they are driving around, you should look serious.... Those one-way roads, where only one car could drive, they can hardly park car there. ... It depends on the car... I've never seen them stopping some new expensive car.... They select also according to what kind of man is driving. ... My experience is that if you wear a hood and dark glasses, you are a clear target."

- P3: "I knew some places where policemen used to park, so I avoided these places."

- P2: "The guy should concentrate, look around, and behave inconspicuously."

- P9: "Drive in traffic. In dense traffic they don't stop you. Simply (stay) in a traffic jam."
- P6: "I drive at a quarter past five at morning and I know that they change shifts at that time and you won't encounter them anywhere."

\subsection{Beliefs about alcohol elimination}

Participants mentioned that they (ignorantly) believed that alcohol might be eliminated from the blood by food or drink:

- P1: "No one believes about the (length of) elimination. (They believe) those myths as food and fat and lard."

- P4: "People say 'It will be OK if you eat or you drink water."”

- P3: "I think that water and fat don't eliminate alcohol, but they might help with the elimination, so that you don't feel like vomiting later... I always tried to drink a lot of water."

One participant believed that tablets he bought might eliminate alcohol in blood:

- P3: "I used to buy some ethanol capsules to reduce the alcohol in my blood. ... I don't know how much alcohol it would erase. I took it for prevention."

Several participants believed that alcohol might be eliminated by sleep:

- P8: "I always thought that if a man drinks a few beers and goes sleep, then only a short time is enough and he is sober in the morning, so I drove unconsciously with residual alcohol."

\subsection{Prevalence of drunk driving}

Participants drove while drunk usually at weekends after a party:

- P1: "It could happen at weekends, once a month..."

Two participants admitted that they drove after drinking alcohol regularly:

- P7: "I drink one shot every morning without eating. It is for the teeth. It is a must. And sometimes I used to drink a beer at 9."

- P5: "I have been driving under the influence for 25 years, maybe with the exception of weekends. ... I went for two beers after work and then drove my car for that short distance (to home)." 
Driving with residual alcohol in the blood seemed to be more socially acceptable than driving while feeling drunk. Several participants spoke about residual alcohol as a common thing:

- P2: "I've never driven drunk, as to get drunk and then drive, no. But with residual alcohol, certainly yes."

\subsection{Knowledge and attitude about the legal punishments for drunk driving}

Participants didn't have a good knowledge of the possible punishments for a DUI before they had committed a related crime:

- P3: "One always knows that there is some big punishment. Doesn't know exactly, but knows that he would be fucked."

- P1: "When it happened to me, I had no knowledge about that (punishment)."

- P2: "I have no knowledge."

- P9: "There is simply not enough information."

Participants thought that the punishments were not the same for all people and that they were not fair. They told several stories about VIP perpetrators who were not punished:

- P4: "It depends who the person is. Whether it is ordinary citizen."

One participant thought that punishments were not fair because they were not related to the severity of the crime:

- P2: "It is not fair in the end. I had an accident and I injured someone... and I had 2,2 promile. You had only 1, no? .... And you were stopped (by the police), but you didn't cause anything... I consider it a little bit unfair, someone who causes an accident should receive more severe penalty."

Another participant replied that his punishment was influenced by the public pressure on judges to give larger penalties at the time when he received his penalty:

- P1: "I spoke with a friend, who is a judge, and he told me that during that time there were affairs that had accumulated, so they received instructions at work: you will punish it a little bit more because of the public... I spoke with a guy who committed something similar and he received a completely different penalty.”

\subsection{Motivation to not drink and drive}

Persecuted drunk drivers might have changed their behavior because of their experience with punishment and their experience with the mentally challenging bureaucratic process of license revocation:

- P1: "It is not a pleasant situation. I had to even be processed in court... If I go to some event, I try to not drive the next day or, if I drive, then at the next evening."

- P4: "When it happens to you, you have learned something for the future, at least. You know that you won't do such a stupid thing. It will change you somehow, it will change your lifestyle and you do things differently."

- P8: "Now I take care about the residual alcohol, I use that rim on idnes.cz web."

For most of participants the hardest punishment was the long-time suspension of their driver's license, partly because of driving as a part of their work:

- P8: "The worst was waiting. I waited for my driver's license for half a year."

The complicated process of getting the license back was also perceived as part of the punishment:

- P8: “... I took holidays in my job in order to get my driver's license back. I had to take four days of holidays... That was the hardest punishment. So many holidays!"

One participant mentioned that the most motivating punishment was community service and prison:

- P6: "The worst was the community service, which I received instead of a fine. ... It cost me a lot of holidays days in my job. ... If they wanted to scare me, then it would only be by prison."

The only female among participants mentioned that her bad conscience was more important for her than sanctions (she caused an accident under the influence of alcohol):

- P2: “Any sanctions don't matter for me, probably. Even losing my driver's license would not limit me, but the moral side of the thing. ... It would bother me morally."

Other participant mentioned the social consequences of being punished for a crime as being the most motivational:

- P8: "The biggest deterrent is that they would not excuse it in my job again, so they would fire me." 


\section{DISCUSSION}

Drunk drivers justified their behavior by believing that they were not so drunk, not thinking of drunk driving as a problem, and proving to be willing to drive despite knowing they were drunk because they felt they needed to or because they would only drive a short distance. These are the same as the most common reasons given in the United States (Kulick \& Rosenberg, 2000) and Spain (Alonso et al., 2015). Different from the American research was that none of the drivers mentioned that he was the least drunk in the group. This might have been caused by the fact that traveling by car with friends in order to drink is less common in the Czech Republic than in the U.S.

Some strategies used by Czech drivers to minimize the risks of driving while drunk are similar as those reported by Kulick and Rosenberg (2000) for the United States: using side streets and one-way roads, and concentrating on driving. Additionally, Czech drivers might drive in morning hours, at times when patrols change shifts, as the second car in a row or follow a friend in another car, with appropriate clothes, while focusing on following the rules, or driving in a traffic jam. These strategies result from the drivers' opinions about police behavior.

People ignorantly believed that alcohol could be eliminated from the blood by eating or drinking water, while in fact food might lower its absorption into the blood only while it is in stomach or intestine. One participant also believed that some capsules might eliminate alcohol from the blood. Other participants believed that alcohol might be eliminated by a quick nap. The fact is, however, that the only way to eliminate alcohol from the blood is by waiting (quite a long) amount of time until alcohol dehydrogenase eliminates it.

Participants usually didn't drink and drive often, with two exceptions. Drunk driving usually happened at weekends. Their knowledge about the legal punishments was not clear. They thought the sanctions are not fair, because they are not applied evenly to everyone and people with good connections might be treated better than others.

Czech drunk drivers are mostly afraid of having their driver's license taken and facing the social consequences, like problems at work. These are the same things that Australian drunk drivers fear (Lenton et al., 2004). One participant, however, mentioned that drunk driving was primarily a moral problem.

\section{CONCLUSION}

Participants in our sample of Czech drunk drivers are mostly unaware that even a small amount of alcohol might impair their driving ability. They tend to believe that food, water, sleep, and some capsules might eliminate alcohol from the blood. They do not have a good knowledge about the possible legal sanctions or driver's license revocation procedure. They also believe that the probability of being caught by the police for a DUI is much higher than it actually is. On the other hand, they are convinced that they know police strategies for catching drunk drivers and employ various countermeasures.

These are all suggestions for public authorities to improve the way that they inform citizens about the DUI problem. People's awareness of DUI and its effect on driving ability might be improved, for example, by offering them a DUI experience in a special simulator (Hong, Ryu, Cho, Lee \& Lee, 2011). Deep nescience and arrogance may be partly caused by demerit point system, which is considered as insufficient and need to be changed (e.g. Zámečník et al, 2016). Furthermore specific measures against DUI (like driver rehabilitation) or global measures (like graduated driver licensing) need to be introduced. As a good start will be sufficient public campaign with information about the fact that simply waiting might eliminate alcohol and the fact that drunk drivers might be punished with severe sanctions. Also more random breath testing with marketing support is needed as this will result in higher subjective probability of detection.

Acknowledgements: This article was produced with the financial support of the Ministry of Education, Youth and Sports within the National Sustainability Programme I, project of Transport R\&D Centre (LO1610), on the research infrastructure acquired from the Operation Programme Research and Development for Innovations (CZ.1.05/2.1.00/03.0064). 


\section{REFERENCES}

Alonso, F., Pastor, J. C., Montoro, L., \& Esteban, C. (2015). Driving under the influence of alcohol: frequency, reasons, perceived risk and punishment. Substance Abuse Treatment, Prevention, and Policy, 10:11, retrieved from https://substanceabusepolicy. biomedcentral.com. doi: 10.1186/s13011-015-0007-4

Beck, K. H. (1981). Driving while under the influence of alcohol: Relationship to attitudes and beliefs in a college population. The American Journal of Drug and Alcohol Abuse, 8, 377-388.

Beck, K. H., Yan, Alice F., Wang, M. Q., Kerns, T. J., \& Burch, C. A. (2009). The Relationship between Impaired Driving Crashes and Beliefs about Impaired Driving: Do Residents in High Crash Rate Counties Have Greater Concerns about Impaired Driving? Traffic Injury Prevention, 10, 127-133. doi: 10.1080/15389580802594960

DeMichele, M., Lowe, N. C., \& Payne, B. K. (2014). A criminological approach to explain chronic drunk driving. American Journal of Criminal Justice, 39, 292-314. doi: 10.1007/s12103013-9216-4

Finbo, L. (2014). Risk, control and self-identity: Young drunk drivers' experiences with driving under the influence of alcohol and drugs. Nordic Studies on Alcohol and Drugs, 31, 229-243. doi: 10.2478/nsad-2014-0019

Goodfellow, M., \& Kilgore, C. (2014). DUI offenders' beliefs about DUI statutes and DUI law enforcement: Implications for deterrence. Journal of Drug Issues, 44, 269-280. doi: 10.1177/0022042613500052

Greenberg, M. D., Morral, A. R., \& Jain, A. K. (2004). How can repeat drunk drivers be influenced to change? Analysis of the association between drunk driving and DUI recidivists' attitudes and beliefs. Journal of Studies on Alcohol and Drugs, 65, 460-463.

Greenberg, M. D., Morral, A. R., \& Jain, A. K. (2005). Drinkdriving and DUI recidivists' attitudes and beliefs: A longitudinal analysis. Journal of Studies on Alcohol, 66, 640-647.

Hedlund, J. H., \& McCartt, A. T. (2002). Drunk Driving: Seeking Additional Solutions. Washington, DC: AAA Foundation for Traffic Safety. Retrieved from www.aaafoundation.org/pdf/ DrunkDriving-SeekingAdditionalSolutions.pdf

Hong, I. K., Ryu, J. B., Cho, J. H., Lee, K. H., \& Lee, W. S. (2011). Development of a driving simulator for virtual experience and training of drunk driving. Advances in Transportation Studies, 33, 139-148.

Hubicka, B., Laurell, H., \& Bergman, G. (2008). Criminal and alcohol problems among Swedish drunk drivers - Predictors of DUI relapse. International Journal of Law and Psychiatry, 31, 471-478. doi: 10.1016/j.ijlp.2008.09.003.

Jia, K., King, M., Fleiter, J. J., Sheehan, M., Ma, W., Lei, J., \& Zhang, J. (2016). Drunk driving offenders' knowledge and behaviour in relation to alcohol-involved driving in Yinchuan and a comparison with Guangzhou, China. Transportation Research Part F, 38, 182-193. doi: 10.1016/j.trf.2015.12.011

Kechagias, S., Jonsson, K. A., Norlander, B., Carlsson, B., \& Jones, A. W. (1997). Low-dose aspirin decreases blood alco- hol concentrations by delaying gastric emptying. Eur. J. Clin. Pharmacol., 53, 241-246. doi: 10.1007/s002280050369

Kulick, D., \& Rosenberg, H. (2000). Assessment of university students' coping strategies and reasons for driving in high-risk drinking-driving situations. Accident Analysis and Prevention, 32, 85-94. doi: 10.1016/S0001-4575(99)00060-3

Lenton, S., Fetherston, J., \& Cercarelli, R. (2010). Recidivist drink drivers' self-reported reasons for driving whilst unlicensed-A qualitative analysis. Accident Analysis and Prevention, 42, 637-644. doi: 10.1016/j.aap.2009.10.010

Liourta, E., \& van Empelen, P. (2008). The importance of selfregulatory and goal-conflicting processes in the avoidance of drunk driving among Greek young drivers. Accident Analysis and Prevention, 40, 1191-1199. doi: 10.1016/j.aap.2008.01.002

Mannstead, A. S. R., Parker, D., Stradling, S. G., Reason, J. T., \& Baxter, J. S. (1992). Perceived consensus in estimates of the prevalence of driving errors and violations. Journal of Applied Social Psychology, 22, 509-530. doi: 10.1111/j.1559-1816.1992. tb00987.x

McCarthy, D. M., \& Pedersen, S. L. (2009). Reciprocal associations between drinking-and-driving behavior and cognitions in adolescents. Journal of Studies on Alcohol and Drugs, 70, 536-542.

Mravčík, V., et al. (2014). National Report: The Czech Republic-2013 Drug Situation [Výroční zpráva o stavu ve věcech drog v České republice v roce 2013]. Praha: Úřad vlády České republiky.

Ojaniemi K. K., Lintonen, T. P., Impinen, A. O., Lillsunde, P. M., \& Ostamo, A. I. (2009). Trends in driving under the influence of drugs: A register-based study of DUID suspects during 1977-2007. Accident Analysis and Prevention, 41, 191-196. doi: 10.1016/j.aap.2008.10.011

Pinsky, I., Labouvie, E., Pandina, R., \& Laranjeira, R. (2001). Drinking and driving: pre-driving attitudes and perceptions among Brazilian youth. Drug and Alcohol Dependence, 62, 231-237.

Portman, M., Pentillä, A., Haukka, J., Rajalin, S., Eriksson, C. J. P., Gunnar, T., ... Kuoppasalmi, K. (2013). Profile of a drunk driver and risk factors for drunk driving. Findings in roadside testing in the province of Uusimaa in Finland 19902008. Forensic Science International, 231, 20-27. doi: 10.1016/j. forsciint.2013.04.010

Powell, A. R., \& Single, H. M. (1996). Focus groups. International Journal for Quality in Health Care, 8, 499-504.

Rabiee, F. (2004). Focus-group interview and data analysis. Proceedings of the Nutrition Society, 63, 655-660. doi: 10.1079/ PNS2004399

Ridout, F., Gould, S., Nunes, C., Hindmarch, I. (2003). The effects of carbon dioxide in champagne on psychometric performance and blood-alcohol concentration. Alcohol and Alcoholism, 38, 381-385. doi: 10.1093/alcalc/agg092

Schulze, H., Schumacher, M., Urmeew, R., \& Auerbach, K. (2012). DRUID Final Report: Work performed, main results and recommendations. Federal Highway Research Institute, Germany. Retrieved from http://www.druid-project.eu/Druid/EN/ deliverales-list/deliverables-list-node.html 
Shore, E. E., \& Compton, K. L. (2000). Individual interventions to prevent drunk driving: Types, efficacy, and a theoretical perspective. Journal of Drug Education, 30, 281-289. doi: 10.2190/ V625-RHCW-P7J0-50MQ

Smith, J. A., Flowers, P., \& Larkin, M. (2009). Interpretative phenomenological analysis: Theory, method and research. London, England: SAGE.

Šucha, M., \& Štastná, L. (2015). Chování účastníků dopravního provozu pod vlivem alkoholu [The Behaviour of Road Users under the Influence of Alcohol]. Adiktologie, 15, 77-84.

Švarc, J. (2014). Alkohol a drogy při řízení motorového vozidla a posouzení schopnosti je řídit [Alcohol and drugs in the driving of a motor vehicle and assessment of fitness to drive]. Psychiatrie pro praxi, 15 (3), 129-133.

Watkins, R. L., \& Adler, E. V. (1993). The effect of food on alcohol absorption and elimination patterns. Journal of forensic sciences, 38, 285-91. doi: 10.1520/JFS13407J

Zakhari, S. (2006). Overview: how is alcohol metabolized by the body? Alcohol Research \& Health, 29, 245-254.

Zámečník, P., Gabrhel, V., Kurečková,V., Řezáč, P. (2016). 7 Years of Experience with Demerit Point System in the Czech Republic: Is It Effective? Advances in Human Aspects of Transportation, Orlando (USA), 27. - 31.7.2016. 2016, p. 269-278. 